\title{
Fuzzy Comprehensive Evaluation Method and Its Application in Existing Buildings Safety
}

\author{
WANG Ying ${ }^{1, a^{*}}$, CAI Legang ${ }^{2, b}$ and CHEN Yang ${ }^{3, c}$ \\ 1,2,3 Shanghai Real Estate Science Research Institute, Shanghai, China \\ a08_wangying@tongji.edu.cn, ${ }^{\mathrm{b}}$ cailegang@126.com, ${ }^{\mathrm{c}} 13901929229 @ 163 . c o m$
}

Keywords: Existing buildings, Safety evaluate; Fuzzy mathematics; Analytic hierarchy process Abstract. Based on the investigating and survey of the potential safety hazards of the buildings, a fuzzy comprehensive evaluation method was proposed for the safety evaluation of the existing buildings. First of all, establish a multi-level comprehensive evaluation model for the safety assessment of the existing buildings. Secondly, define the safety levels of the evaluation indexes and factors. Thirdly, determine the weights of the factors according to the analytic hierarchy process (AHP). Fourthly, determine the mathematical model of the fuzzy comprehensive evaluation. At last, define the safety levels of the building and determine the method to evaluate the safety of the building. The fuzzy comprehensive evaluation process was given in this paper and applied to the safety evaluation of an outstanding historical building in Shanghai, which proved that the pro-posed method was applicable to estimate the safety degree of the existing buildings.

\section{Introduction}

Since reform and opening up it was devoted great effort on the reconstruction of the old town and lots of dangerous buildings were dismantled in China. The condition of the buildings and the quality of the environment were improved by means of strengthening the property management. However, the evaluation methods to assess the safety of the existing buildings provided by the related standards and criterions [1-3] in China at present mainly concern the safety of the structure, which take insufficient account of other safety influence factors which probably exist in the process of the design, construction, use and maintaining, management and so on. Therefore, it will be of great importance in establishing a comprehensive evaluation method to evaluate the safety of the existing buildings. The evaluation results should be comprehensively reflect the actual security status of the building, which can provide the basis for the safety management and decision making for the building to guarantee the lives and properties of the human beings, as well as to the social stability and the economic development.

Based on the investigating and survey of the potential safety hazards for the existing buildings, a multi-level comprehensive evaluation model was established for the safety evaluation of the buildings. Considering the subjectivity and fuzziness inevitably exist in the process of evaluation, the safety of the existing building was assessed taking advantage of the fuzzy comprehensive evaluation method, which translates the qualitative evaluation into the quantitative evaluation according to the membership degree theory of the fuzzy mathematics. The fuzzy comprehensive evaluation method has been applied in many fields [4-8]. Using the proposed method, the safety of a historical building in Shanghai was evaluated, which proved that the proposed method has a good applicability on the safety evaluation of the existing buildings.

\section{Comprehensive Evaluation Model for Building Safety Assessment}

Potential Safety Hazards of the Existing Buildings. The safety degree of the building could be reduced due to the potential safety hazards. In order to establish the comprehensive safety evaluation model of the existing buildings, the potential safety hazards of the existing buildings in Shanghai were investigated and analyzed. According to the results, it can be known that the potential safety hazards could be generated due to many reasons which relates to the design, construction, use and maintaining, and management of the 
building [9]. According to the characteristics and reasons, the potential safety hazards could be classified into six categories which respectively referred to many influenced factors, detailed explained as follows.

(1) Hazards related to the project survey, design and construction

Obvious cracks and overlarge deformation maybe appear in the upper structure due to the uneven settlement, incline and slide of the foundation when no professional project survey for the building was con-ducted and the safety incidents maybe occur when the structural design do not conform to the requirements of the current design code, or the building was constructed not according to the drawing, or the construction quality does not satisfy the requirements of the current code for the construction quality acceptance specification.

(2) Hazards related to the structural members

The potential safety hazards could be caused when the structural members are cracked and the width of the cracks do not meet the requirements of the cur-rent design code, or the materials strength do not meet the requirements of the original design, or the deformation and construction do not meet the requirements of the current design code, or the deformation, slip, loose or other damages appear in the construction, etc.

(3) Hazards related to the nonstandard interior deco-ration

The potential safety hazards could be caused when the vertical or horizontal structural components are damaged, or the floor loads are increased, or the illegal building was constructed and no corresponding reinforcement measures were taken to deal with these problems.

(4) Hazards referred to the unfriendly change of the surroundings

The potential safety hazards maybe appear when there are unfriendly changes of the surroundings and the building position is in the main influence range such as precipitation of the groundwater, excavation of the foundation pits, construction of the pile foundation, long-term vibration of the subway, light rail, automobile, etc.

(5) Hazards related to the building appendages

The building appendages include the light boxes, billboards, outside air conditioning machines, burglar meshes, clothes racks, flowerpot shelves, etc. The safety risks may be increased when no rational design of the building appendages was conducted, the connections of the frame and the base material were not strong enough and obvious deformation, sliding and loosening appear in the connections.

(6) Hazards related to the non-structural members

The potential safety hazards could be caused when the bond of the exterior wall bricks and the roofing tile are unreliable, or the construction of the parapet, suspended ceiling and partition wall are not reasonable, some cracks and damages are turned up, or the design of the exterior curtain wall does not meet the requirements of the current design code and deformation and looseness appear in the connections of the curtain wall.

Comprehensive Evaluation Model for the Safety Assessment of the Existing Buildings. According to the classification of the potential safety hazards of the building, a multi-level comprehensive evaluation model for the safety assessment of the existing buildings was established, as shown in Table 1. There are six evaluation indexes in the second level of the model and each index related to multiple influence factors (a total of 24), which belong to the third level of the model. The evaluation of factors basically on the results of the daily inspection and testing of the building, therefore, the proposed model is applicable in the daily safety management of the existing buildings.

\section{Fuzzy Comprehensive Evaluation for the Safety Evaluation of Existing Buildings}

Definition of the Safety Levels of the Evaluation Indexes and Factors. According to the fuzzy comprehensive evaluation method, the safety of the evaluation indexes and factors will be assessed firstly in the process of the safety evaluation of the building. Therefore, the definition and the assessment basis for the safety levels of the indexes and factors should be given in the first place. According to the different degree of 
meeting the requirements of the current specification, the safety levels of the factors were divided into four grades as a, b, c, d from good to bad. As an example, the safety levels of the structural members were given in Table 2. The safety levels of the indexes were divided into four grades as A, B, C, D from good to bad and the assessment basis were given in Table 3.

Membership Degree of the Evaluation Factor. Considering the subjectivity and fuzziness inevitably exist in the process of evaluation, the membership function in fuzzy mathematics [10] was introduced. The safety of the factors is considered as a set $\mathrm{U}$ and the safety level of the factors is considered as the fuzzy subset A of U. The membership degrees to each safety level could be assessed according to the conforming degree to the requirements of the corresponding standards, combined with previous research results and practical experience. The evaluation criterions could be qualitatively described as Conform, Roughly conform, Like conform and like not conform, Roughly not conform and Not conform five grades and quantitatively described as 1, 0.75, 0.5, 0.25, 0 respectively, as shown in Table 4.

Weights of the Evaluation Factors. The weights of the evaluation factors are confirmed by AHP and the method to define the relative scales is shown in Table 5. Some experts in the related fields were invited to evaluate the factors. For each factor, the final weight is the average value of all the single weight given by the experts, shown as $A_{i}=\left(a_{i 1} a_{i 2} \ldots a_{i j}\right)$ and the values were given in Table 1 .

Table 1 A Multi-level Comprehensive Evaluation Model

\begin{tabular}{|c|c|c|c|}
\hline Objective & Indexes & Factors & $\begin{array}{c}\text { Weight } \\
\text { s }\end{array}$ \\
\hline \multirow{6}{*}{$\begin{array}{c}\text { Safety } \\
\text { evaluation } \\
\text { system } U\end{array}$} & $\begin{array}{l}\text { Project survey, design } \\
\text { and construction } U_{1}\end{array}$ & $\begin{array}{ll}u_{1}: & \text { project survey } \\
u_{2}: \text { design } \\
u_{3}: \text { construction }\end{array}$ & $\begin{array}{l}0.46 \\
0.32 \\
0.22\end{array}$ \\
\hline & Structural members $U_{2}$ & $\begin{array}{l}u_{4}: \text { crack } \\
u_{5}: \text { material strength } \\
u_{6}: \text { deformation } \\
u_{7}: \text { construction }\end{array}$ & $\begin{array}{l}0.26 \\
0.35 \\
0.25 \\
0.14\end{array}$ \\
\hline & $\begin{array}{l}\text { Nonstandard interior } \\
\text { decoration } U_{3}\end{array}$ & $\begin{array}{l}u_{8}: \text { vertical structural components } \\
u_{9}: \text { horizontal structural components } \\
u_{10}: \text { floor loads increased } \\
u_{11}: \text { illegal buildings constructed }\end{array}$ & $\begin{array}{l}0.46 \\
0.24 \\
0.15 \\
0.15\end{array}$ \\
\hline & $\begin{array}{l}\text { Unfriendly change of } \\
\text { the surroundings } U_{4}\end{array}$ & $\begin{array}{l}u_{12}: \text { precipitation of the groundwater, } \\
u_{13}: \text { excavation of the foundation pits } \\
u_{14}: \text { construction of the pile foundation } \\
u_{15}: \text { long-term vibration of the subway, light rail, } \\
\text { automobile }\end{array}$ & $\begin{array}{l}0.16 \\
0.46 \\
0.27 \\
0.11\end{array}$ \\
\hline & $\begin{array}{l}\text { Building appendages } \\
U_{5}\end{array}$ & $\begin{array}{l}u_{16}: \text { light boxes, billboards } \\
u_{17}: \text { outside air conditioning machine } \\
u_{18}: \text { burglar mesh, clothes racks, flowerpot } \\
\text { shelves, etc }\end{array}$ & $\begin{array}{l}0.40 \\
0.40 \\
0.20\end{array}$ \\
\hline & $\begin{array}{l}\text { Non-structural } \\
\text { members } U_{6}\end{array}$ & $\begin{array}{l}u_{19}: \text { exterior curtain wall } \\
u_{20}: \text { exterior wall bricks and } \\
u_{21}: \text { parapet } \\
u_{22}: \text { roofing tile } \\
u_{23}: \text { suspended ceiling } \\
u_{24}: \text { partition wall }\end{array}$ & $\begin{array}{l}0.43 \\
0.20 \\
0.13 \\
0.10 \\
0.07 \\
0.07\end{array}$ \\
\hline
\end{tabular}

Mathematical Model of the Fuzzy Comprehensive Evaluation. According to the fuzzy mathematics the fuzzy relations of each element in the factor sets $\mathrm{U}, \mathrm{U}=\left\{u_{1}, u_{2}, \ldots, u_{\mathrm{n}}\right\}, n=24$, and each element in the evaluation sets $\mathrm{V}, \mathrm{V}=\left\{v_{1}, v_{2}, v_{3}, v_{\mathrm{m}}\right\}, m$ $=4$, could be expressed by the fuzzy matrix R, expressed as Eq. 1 . 
Table 2 Safety Levels and Evaluation Basis for the Safety Evaluation Factors of the Structural Members (index $\left.U_{2}\right)$

\begin{tabular}{|c|c|}
\hline Evaluation Factors & SafetyLevels and Ealuation Basis \\
\hline Crack & $\begin{array}{l}a: \text { No significant crack or only minor cracks. } \\
b: \text { The cracks widths are less than the requirements of the current design } \\
\text { specification. } \\
c \text { : The cracks widths are greater than the requirements of the current design } \\
\text { specification, but less than the requirements of the current Standard of Dangerous } \\
\text { Buildings Appraisal. } \\
d \text { :The cracks widths are greater than the requirements of the current Standard of } \\
\text { Dangerous Buildings Appraisal. }\end{array}$ \\
\hline Material Strength & $\begin{array}{l}a \text { : The materials strength conforms to the requirements of the original design. } \\
b: \text { The materials strength is lower than the requirements of the original design, but } \\
\text { not less than } 5 \% \text {. } \\
\text { c: The materials strength is lower than } 5 \% \sim 10 \% \text { of the requirements of the } \\
\text { original design. } \\
d \text { : The materials strength is lower than more than } 10 \% \text { of the requirements of the } \\
\text { original design. }\end{array}$ \\
\hline Deformation & $\begin{array}{l}a \text { : The deformation value is lower than the current design specification } \\
\text { requirements. } \\
b, c \text { : The deformation value is greater than the requirements of the current design } \\
\text { specification, but less than the requirements of the current Standard of Dangerous } \\
\text { Buildings Appraisal. The deformation value of level c is greater than level b. } \\
d \text { :The deformation value is greater than the requirements of the current Standard } \\
\text { of Dangerous Buildings Appraisal. }\end{array}$ \\
\hline Construction & $\begin{array}{l}a, b \text { : The design of the constructions conforms to the requirements of the current } \\
\text { design code and no deformation, slip, loose or other damages or only partial } \\
\text { surface defect appear in the constructions. The condition of level a is better than } \\
\text { level b. } \\
c, d \text { : The constructions have serious defects and obvious deformation, slip, loose } \\
\text { or other damages appear in the constructions. The condition of level c is better } \\
\text { than leveld. }\end{array}$ \\
\hline
\end{tabular}

Table 3 Safety levels and evaluation basis for the safety evaluation indexes of the building

\begin{tabular}{|c|c|c|}
\hline Safety levels & Evaluation basis & Assessment coefficient $S$ \\
\hline A & $\begin{array}{l}\text { There is no or only slight unsafe factors and the } \\
\text { safety of the building is not affected. }\end{array}$ & $80 \leq S<100$ \\
\hline B & $\begin{array}{l}\text { Some unsafe factors exist and the safety of the } \\
\text { building is roughly not affected. There may be a } \\
\text { handful of unsafe factors need to be processed. }\end{array}$ & $60 \leq S<80$ \\
\hline $\mathrm{C}$ & $\begin{array}{l}\text { Some serious unsafe factors exist and the building } \\
\text { safety is significantly affected. The corresponding } \\
\text { measures should be adopted to deal with the uns afe } \\
\text { factors. }\end{array}$ & $40 \leq S<60$ \\
\hline $\mathrm{D}$ & $\begin{array}{l}\text { Some serious unsafe factors exist and seriously } \\
\text { influence the building safety. The corresponding } \\
\text { measures must be taken immediately to deal with the } \\
\text { unsafe factors. }\end{array}$ & $0<S<40$ \\
\hline
\end{tabular}


Table 4 Quantitative description for the safety levels of the safety evaluation factors

\begin{tabular}{lccccc}
\hline \multirow{2}{*}{$\begin{array}{c}\text { Level } \\
\text { a } b, c, d)\end{array}$} & Conform & $\begin{array}{c}\text { Roughly } \\
\text { conform }\end{array}$ & $\begin{array}{c}\text { Like conform and like not } \\
\text { conform }\end{array}$ & $\begin{array}{c}\text { Roughly not } \\
\text { conform }\end{array}$ & Not conform \\
\hline $\begin{array}{c}\text { Quantitative } \\
\text { description }\end{array}$ & \multicolumn{2}{c}{1} & 0.75 & 0.5 & 0.25 \\
\hline $\mathrm{R}=\left[\begin{array}{cccc}r_{11} & r_{12} & \cdots & r_{1 \mathrm{~m}} \\
r_{21} & r_{22} & \cdots & r_{2 \mathrm{~m}} \\
\cdots & \cdots & \cdots & \cdots \\
r_{n 1} & r_{n 2} & \cdots & r_{\mathrm{nm}}\end{array}\right]$.
\end{tabular}

where $r_{\mathrm{ij}}=$ the membership degree of the factor $i$ to the safety level $j$.

For each index, the fuzzy comprehensive evaluation matrix $\mathrm{B}, \mathrm{B}=\left(b_{1} b_{2} \ldots b_{\mathrm{m}}\right)$, can be established according to Eq. 2 .

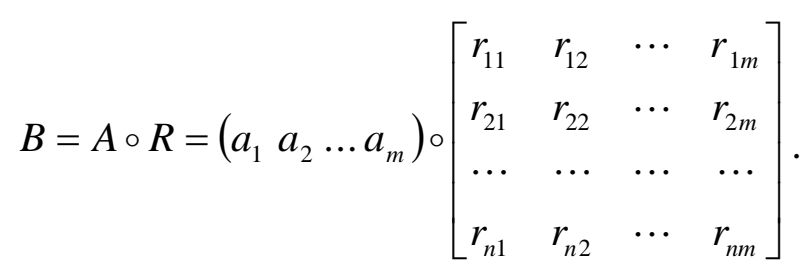

where $m=4, a_{\mathrm{i}}=$ the weight of factor $i$. The symbolic of "。" represents the fuzzy arithmetic and the fuzzy operator of multiplication addition was adopted to determine the fuzzy comprehensive evaluation vector $b_{\mathrm{j}}$ shown as Eq. 3, which also called as Weighted Average method.

$$
b_{j}=\min \left\{1, \sum_{i=1}^{n} a_{i} r_{i j}\right\} .
$$

Safety Evaluation of the Indexes. The safety level of the index is determined by the assessment coefficient $S$, calculated by Eq. 4 .

$$
S=\sum_{i=1}^{n} x_{i} b_{i}
$$

where $x_{\mathrm{i}}=$ the predefined values corresponding to level $i, b_{\mathrm{i}}=$ the membership degree to level $i$ for the index.

The predefined values corresponding to level A, B, C, D were respectively $90,70,50$ and 30 and the ranges of the assessment coefficient $S$ to evaluate the safety level of the indexes were shown in Table 3 . For example, the fuzzy comprehensive evaluation vector for an index was $\mathrm{B}=\left\{\begin{array}{lll}0.06 & 0.35 & 0.330 .26\end{array}\right\}$, according to Eq. 4 ,

$$
S=0.06 \times 90+0.35 \times 70+0.33 \times 50+0.26 \times 30=54.2
$$

According to the corresponding relationship between $S$ and the safety level of the index, the safety level of the index was assessed as level C. 
Definition of the safety levels of the building. Considering that the indexes are relatively independent of each other and the weight set of the indexes is hard to be obtained, the safety levels of the indexes are hard to be divided by the fuzzy comprehensive evaluation vector directly. The safety level and serviceability level of the structure are assessed according to the proportion of each safety and serviceability level of the structural components in the reference [11]. With reference to this method, the safety level of the building could be assessed by the numbers of each safety level of the indexes. The safety levels of the building were divided into four classes as I = II , III and IV from good to bad and their definitions and evaluation basis were given in Table 6. The safety management advices for each level of the building were also given in Table 6 .

The flow chart of the fuzzy comprehensive evaluation of the existing buildings was given in Fig. 1 .

Table 5 Method to define the relative scales

\begin{tabular}{|c|c|c|}
\hline Scale $u_{i j}$ & Definition & Scale $\mathrm{u}_{\mathrm{ji}}$ \\
\hline 1 & Equal importance, to the upper criteria, these two are equal important & 1 \\
\hline 3 & $\begin{array}{l}\text { Moderate importance, to the upper criteria, the } i_{\text {th }} \text { criteria is moderate } \\
\text { important than the } j_{\text {th }} \text { criteria }\end{array}$ & $1 / 3$ \\
\hline 5 & $\begin{array}{l}\text { Essential importance, to the upper criteria, the } i_{\text {th }} \text { criteria is essential } \\
\text { important than the } j_{\text {th }} \text { criteria }\end{array}$ & $1 / 5$ \\
\hline 7 & $\begin{array}{l}\text { Demonstrated importance, to the upper criteria, the } i_{\text {th }} \text { criteria is } \\
\text { demonstrated important than the } j_{\text {th }} \text { criteria }\end{array}$ & $1 / 7$ \\
\hline 9 & $\begin{array}{l}\text { Absolute importance, to the upper criteria, the } i_{\text {th }} \text { criteria is absolute } \\
\text { important than the } j_{\text {th }} \text { criteria }\end{array}$ & $1 / 9$ \\
\hline $2,4,6,8$ & $\begin{array}{l}\text { The relatively importance of the } i_{\text {th }} \text { criteria and the } j_{\text {th }} \text { criteria is between } \\
\text { the above }\end{array}$ & $\begin{array}{l}1 / 2,1 / 4,1 / 6,1 \\
/ 8\end{array}$ \\
\hline
\end{tabular}

Table 6 Safety levels and evaluation basis for the safety evaluation of the building

\begin{tabular}{|c|c|c|c|}
\hline $\begin{array}{l}\text { Safety } \\
\text { level }\end{array}$ & Evaluation basis & Definition & Advice \\
\hline I & $\begin{array}{l}\text { No index of level B, C, D, or } \\
\text { no index of level C, D, only } \\
\text { one index of level B, others } \\
\text { are all A. }\end{array}$ & $\begin{array}{l}\text { The main structure of the building is } \\
\text { in good condition and no or only } \\
\text { slight potential safety hazard exist. } \\
\text { The building is overall safe. }\end{array}$ & $\begin{array}{l}\text { Normal use, normal management } \\
\text { and maintenance. }\end{array}$ \\
\hline II & $\begin{array}{l}\text { No index of level C, D, more } \\
\text { than one index of level B, or } \\
\text { no index of level D, only one } \\
\text { index of level C. }\end{array}$ & $\begin{array}{l}\text { Some potential safety hazards exist } \\
\text { in local place of the building. The } \\
\text { building is generally safe as a whole. }\end{array}$ & $\begin{array}{l}\text { Normal use, continued monitoring } \\
\text { and observation. }\end{array}$ \\
\hline III & $\begin{array}{l}\text { No index of levelD, more than } \\
\text { one index of level C, or only } \\
\text { one index of level D. }\end{array}$ & $\begin{array}{l}\text { Serious potential safety hazards } \\
\text { exist in the building and the overall } \\
\text { safety of the building is significantly } \\
\text { affected. }\end{array}$ & $\begin{array}{l}\text { Further safety appraisal, use after } \\
\text { measures be taken to deal with the } \\
\text { potential safety hazards. }\end{array}$ \\
\hline IV & $\begin{array}{l}\text { More than one index of level } \\
\text { D. }\end{array}$ & $\begin{array}{l}\text { Very serious potential safety } \\
\text { hazards exist in the building and the } \\
\text { building is not safe. }\end{array}$ & $\begin{array}{l}\text { Prohibited use, immediate } \\
\text { measures should be taken to deal } \\
\text { with the potential safety hazards or } \\
\text { demolish the building. }\end{array}$ \\
\hline
\end{tabular}

\section{Application}

Using the fuzzy comprehensive evaluation method proposed in this paper, the safety of an outstanding historical building in Shanghai (shown in Fig. 2) was evaluated. The building is a 8 layers reinforced concrete frame structure (local is shear wall structure). The building includes two parts, the outer ring and inner ring, 
which were separated by the settlement joint. The outer ring of the build was built earlier (in 1932) than the inner ring. The building was reconstructed and strengthened for many times.

According to the results of the daily inspection and testing and field investigation of the building, the safety of the six evaluation indexes given in Table 1 were assessed and the results were listed in Table 7. Partial damage conditions of the building were shown in Fig. 3.

According to Table 5, the outer ring of the building was evaluated as level III and the inner ring of the building was evaluated as level II.

\section{Commission accepted}

Investigation of the damage situation of the safety assessment factors of the building according to consulting the results of the daily inspection and testing and field investigation of the building.

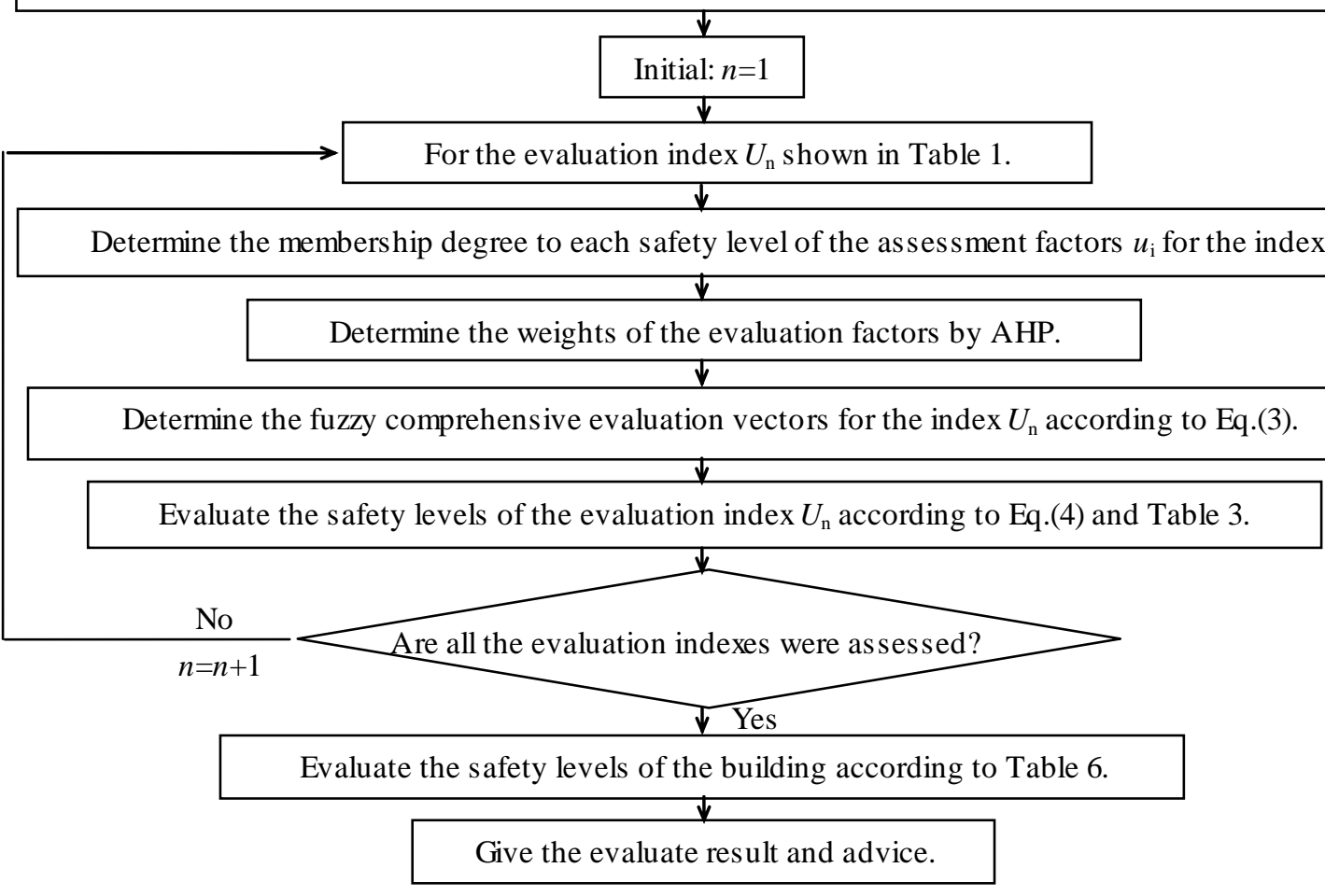

Figure 1 The flow chart of the fuzzy comprehensive evaluation of the existing buildings
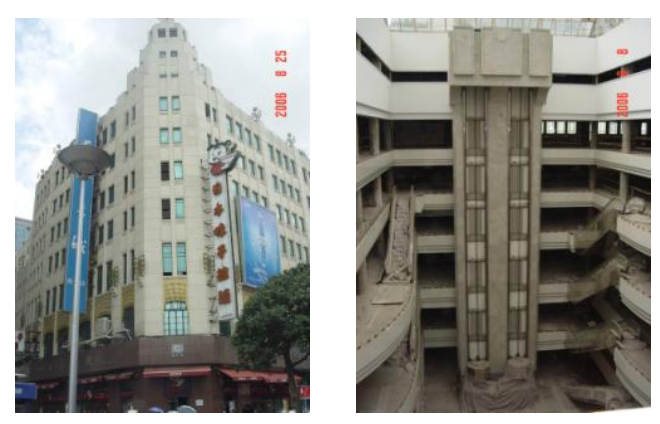

(a) Exterior photograph (b) Interior photograph

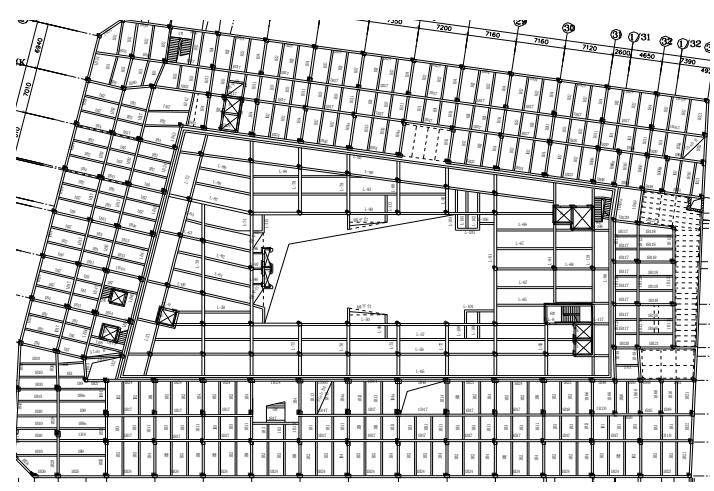

(c) Plan sketch

Figure 2 Pictures and layout of the outstanding historical building in Shanghai 


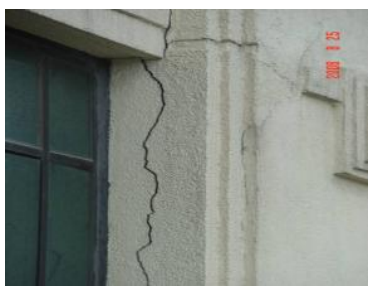

(a) Vertical crack in the wall

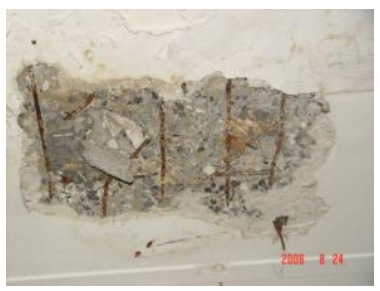

(d) Corrosion of reinforcement in the bottom of the floor slab

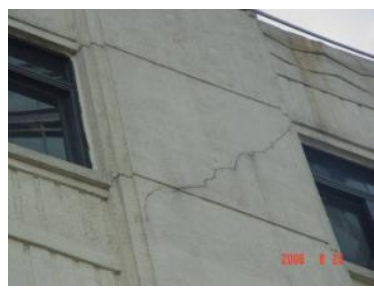

(b) Inclined crack in the wall

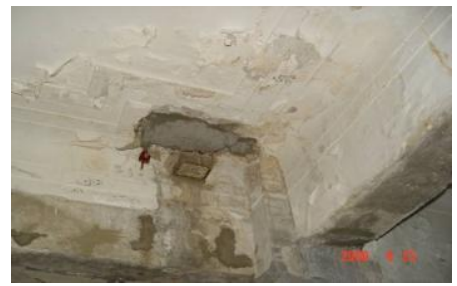

(e) Water seepage and paint peeling in the bottom of the floor slab

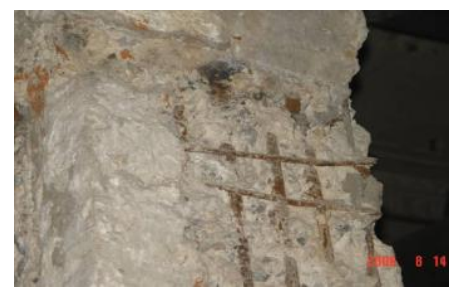

(c) Corrosion of steel rebars in column

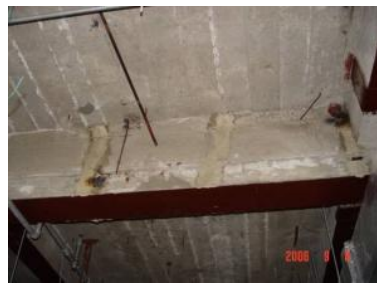

(f) Strengthened by the bonded steel plate for the beam

Figure 3 Investigation of the damage situation of the building

Table 7 Assessment Results of the Example

\begin{tabular}{|c|c|c|c|c|c|c|c|c|c|}
\hline \multirow{2}{*}{\multicolumn{2}{|c|}{$\begin{array}{l}\text { Safety Level } \\
\text { of the } \\
\text { Building }\end{array}$}} & \multirow{2}{*}{\multicolumn{3}{|c|}{$\begin{array}{l}\text { Safety Level of the } \\
\text { Indexes }\end{array}$}} & \multicolumn{5}{|c|}{ Safety Level of the Factors } \\
\hline & & & & & \multicolumn{3}{|c|}{ Membership Degree to Each Level for $u_{\mathrm{i}}$} & \multicolumn{2}{|c|}{ Safety Level } \\
\hline $\begin{array}{c}\text { Outer } \\
\text { ring }\end{array}$ & $\begin{array}{c}\text { Inner } \\
\text { ring }\end{array}$ & $U_{\mathrm{i}}$ & $\begin{array}{c}\text { Outer } \\
\text { ring }\end{array}$ & $\begin{array}{c}\text { Inner } \\
\text { ring }\end{array}$ & $u_{\mathrm{i}}$ & Outer ring & Inner ring & $\begin{array}{c}\text { Outer } \\
\text { ring }\end{array}$ & $\begin{array}{c}\text { Inner } \\
\text { ring }\end{array}$ \\
\hline \multirow[t]{24}{*}{ III } & II & $U_{1}$ & $\mathrm{~B}$ & $\mathrm{~B}$ & $u_{1}$ & $(0,0.75,0.25,0)$ & $(0,0.75,0.25,0)$ & $\mathrm{b}$ & $\mathrm{b}$ \\
\hline & & & & & $u_{2}$ & $(0,0.25,0.75,0)$ & $(0.25,0.75,0,0)$ & $\mathrm{c}$ & $\mathrm{b}$ \\
\hline & & & & & $u_{3}$ & $(0,0.75,0.25,0)$ & $(0,0.75,0.25,0)$ & $\mathrm{b}$ & $\mathrm{b}$ \\
\hline & & $U_{2}$ & $\mathrm{C}$ & $\mathrm{B}$ & $u_{4}$ & $(0,0.35,0.65,0)$ & $(0,0.75,0.25,0)$ & $\mathrm{c}$ & $\mathrm{b}$ \\
\hline & & & & & $u_{5}$ & $(0,0,0.3,0.7)$ & $(0.6,0.4,0,0)$ & $\mathrm{d}$ & $\mathrm{a}$ \\
\hline & & & & & $u_{6}$ & $(0.2,0.8,0,0)$ & $(0.7,0.3,0,0)$ & $\mathrm{b}$ & $\mathrm{a}$ \\
\hline & & & & & $u_{7}$ & $(0,0.25,0.75,0)$ & $(0.25,0.75,0,0)$ & $\mathrm{c}$ & $\mathrm{b}$ \\
\hline & & $U_{3}$ & $\mathrm{~B}$ & A & $u_{8}$ & $(0,0.75,0.25,0)$ & $(0.75,0.25,0,0)$ & $\mathrm{b}$ & $\mathrm{a}$ \\
\hline & & & & & $u_{9}$ & $(0,0.25,0.75,0)$ & $(0,0.6,0.4,0)$ & $\mathrm{b}$ & $\mathrm{b}$ \\
\hline & & & & & $u_{10}$ & $(0.6,0.4,0,0)$ & $(0.8,0.2,0,0)$ & $\mathrm{b}$ & a \\
\hline & & & & & $u_{11}$ & $(0.8,0.2,0,0)$ & $(0.8,0.2,0,0)$ & $\mathrm{a}$ & $\mathrm{a}$ \\
\hline & & $U_{4}$ & $\mathrm{C}$ & $\mathrm{B}$ & $u_{12}$ & $(0.6,0.4,0,0)$ & $(0.7,0.3,0,0)$ & $\mathrm{a}$ & $\mathrm{a}$ \\
\hline & & & & & $u_{13}$ & $(0,0.2,0.8,0)$ & $(0,0.4,0.6,0)$ & $\mathrm{c}$ & $\mathrm{c}$ \\
\hline & & & & & $u_{14}$ & $(0,0.3,0.7,0)$ & $(0,0.75,0.25,0)$ & $\mathrm{c}$ & $\mathrm{b}$ \\
\hline & & & & & $u_{15}$ & $(0,0.25,0.75,0)$ & $(0,0.4,0.6,0)$ & $\mathrm{c}$ & $\mathrm{c}$ \\
\hline & & $U_{5}$ & $\mathrm{~B}$ & A & $u_{16}$ & $(0,0.6,0.4,0)$ & $(0.75,0.25,0,0)$ & $\mathrm{b}$ & $\mathrm{a}$ \\
\hline & & & & & $u_{17}$ & $(0.25,0.75,0,0)$ & $(0.4,0.6,0,0)$ & $\mathrm{b}$ & $\mathrm{b}$ \\
\hline & & & & & $u_{18}$ & $(0.75,0.25,0,0)$ & $(0.75,0.25,0,0)$ & $\mathrm{a}$ & $\mathrm{a}$ \\
\hline & & $U_{6}$ & $\mathrm{~B}$ & $\mathrm{~B}$ & $u_{19}$ & $(0.75,0.25,0,0)$ & $(0.75,0.25,0,0)$ & $\mathrm{a}$ & $\mathrm{a}$ \\
\hline & & & & & $u_{20}$ & $(0.25,0.75,0,0)$ & $(0.4,0.6,0,0)$ & $\mathrm{b}$ & $\mathrm{b}$ \\
\hline & & & & & $u_{21}$ & $(0,0.4,0.6,0)$ & $(0,0.8,0.2,0)$ & $\mathrm{c}$ & $\mathrm{b}$ \\
\hline & & & & & $u_{22}$ & $(1.0,0,0,0)$ & $(0.8,0.2,0,0)$ & $\mathrm{a}$ & $\mathrm{a}$ \\
\hline & & & & & $u_{23}$ & $(0,0.75,0.25,0)$ & $(0,0.8,0.2,0)$ & $\mathrm{b}$ & $\mathrm{b}$ \\
\hline & & & & & $u_{24}$ & $(0,0,0.75,0.25)$ & $(0,0,0.75,0.25)$ & $\mathrm{c}$ & $\mathrm{c}$ \\
\hline
\end{tabular}




\section{Summary}

1) Based on the investigating and survey of the potential safety hazards for the existing buildings, a multi-level comprehensive evaluation model was established for the safety evaluation of the existing buildings. The proposed model is applicable in the daily safety management for the existing buildings.

2) Taking advantage of the fuzzy comprehensive evaluation method, the safety of the existing buildings could be assessed. The flow chart of the fuzzy comprehensive evaluation of the existing buildings was given in this paper and applied to the safety evaluation of an outstanding historical building in Shanghai, which proved that the proposed method was applicable to estimate the safety degree of the existing buildings.

\section{Acknowledgements}

This research has been financed by the Research Project of Shanghai Science and Technology Committee, China (No. 14dz1207000), which are greatly appreciated.

\section{References}

[1] MOHURD, Standard of Dangerous Buildings Appraisal (JGJ 125-99), China Arch. \& Building Press, Beijing, 1999. In Chinese.

[2] MOHURD, Standard for appraisal of reliability of industrial buildings and structures (GB50144-2008), China Arch. \& Building Press, Beijing, 2008. In Chinese.

[3] MOHURD, Standard for appraiser of reliability of civil buildings (GB 50292-2014), China Arch. \& Building Press, Beijing, 2014. In Chinese.

[4] Ch.H. Li, H.M Li, X.H Yun, Construction safety management performance evaluation based on fuzzy analytic hierarchy process, J. Xi'an Uni. Arc. \&Technol. (Natural Science Edition) 41(2) (2009) 207-212. In Chinese.

[5] Y. Huang, H.M. Li, Ch.Y. Yuan, A Practical Research of Claim Risks System based on Fuzzy Comprehensive Assessment, J. Xi'an Uni. Arc. \&Technol. (Natural Science Edition) 38(6) (2006) 882-886. In Chinese.

[6] M. Dagdeviren, I. Yuksel, Developing a fuzzy analytic hierarchy process (AHP) model for behavior-based safety management, Info. Sci. 178 (2008) 1717-1733.

[7] T. Osman, A.O. Bafail, M.S. Reda, et al, Construction projects selection and risk assessment by fuzzy AHP and fuzzy TOPSIS methodologies, Appl. Soft Comp. 17 (2014) 105-116.

[8] G.W. Yi, H.L. Qin, Fuzzy Comprehensive Evaluation of Fire Risk on High-Rise Buildings, Proc. Eng. 11(2011) 620-624.

[9] L.g. Cai, X.J. Chen, Q.X. Liu, The Investigation of Safety Incipient Fault in Safety Assessment for Buildings, Housing Sci. 4 (2007)36-39. In Chinese.

[10]Z.Z. Peng, Y.Y. Sun, Applied Fuzzy Mathematics, Wuhan, Wuhan Uni. Press, 2002. In Chinese.

[11] MOHURD, Standard for appraiser of reliability of civil buildings (GB 50292-2014), China Arch. \& Building Press, Beijing, 2014. In Chinese. 